\title{
Pola Teknik Budi Daya dan Sifat Kimia Tanah yang Berhubungan dengan Penyakit Blas pada Padi Sawah
}

\author{
Pattern of Cultivation Technique and Soil Chemical Properties \\ Associated with Blast Disease of Paddy Rice
}

\author{
Yuyun Andriyani dan Suryo Wiyono* \\ Institut Pertanian Bogor, Bogor 16680
}

\begin{abstract}
ABSTRAK
Penyakit blas yang disebabkan Pyricularia oryzae merupakan penyakit yang paling merusak di semua negara penghasil padi. Namun epidemi penyakit blas pada padi di Indonesia tergolong baru, yang sebelumnya dikenal sebagai penyakit utama padi gogo. Penelitian ini bertujuan menganalisis faktor agronomi dan tanah yang berhubungan dengan perkembangan penyakit blas padi. Penyakit blas dinilai pada 50 petak sawah menggunakan sistem skor IRRI. Petani yang menanam padi di petak pengamatan diwawancarai menggunakan kuesioner terstruktur tentang teknik budi daya yang meliputi varietas, pupuk organik dan pupuk sintetik NPK, penggunaan insektisida, fungisida, dan herbisida. Analisis kimia tanah dilakukan terhadap $\mathrm{pH}, \mathrm{C}$ organik, $\mathrm{N}, \mathrm{P}, \mathrm{K}, \mathrm{Ca}, \mathrm{Mg}, \mathrm{Si}, \mathrm{Zn}, \mathrm{Mn}, \mathrm{Cu}$ pada tanah yang diperoleh dari ledakan penyakit blas berat dan ringan, dengan lima sampel untuk masing-masing kategori. Data faktor teknik budi daya (varietas, pemupukan, penggunaan pestisida, penggunaan bahan organik) ditabulasi silang dalam tabel kontingensi terhadap dua tingkat keparahan penyakit, dan selanjutnya dianalisis tingkat nyata keterkaitan. Sifat kimia tanah plot yang keparahan penyakitnya berbeda dianalisis. Faktor agronomi yang berhubungan dengan tingginya keparahan penyakit blas padi sawah ialah penggunaan varietas Ciherang, penggunaan pestisida frekuensi tinggi, dan penggunaan herbisida. Sifat tanah yang berhubungan dengan tingkat epidemi ledakan penyakit ialah kadar N, P, K, S, Si, dan unsur mikro tanah.
\end{abstract}

Kata kunci: herbisida, Pyricularia oryzae, unsur makro, unsur mikro, varietas Ciherang

\begin{abstract}
Blast caused by Pyricularia oryzae is a most destructive diseases of rice in all rice producing countries. However severe blast infestation on paddy rice in Indonesia is relatively new, it is previously known as main disease of upland rice. This study aimed to determine the agronomic and soil factors associated with development of blast disease of paddy rice. Blast disease was assessed on 50 plots of paddy field by using IRRI score system. Farmers growing paddy rice in observed plots were interviewed using structured questionnaire on cultivation techniques includes varieties, NPK organic and synthetic fertilizers rate, insecticides, fungicides and herbicides uses. Soil chemical analysis was done on $\mathrm{pH}, \mathrm{C}$ organic, $\mathrm{N}, \mathrm{P}, \mathrm{K}, \mathrm{Ca}, \mathrm{Mg}, \mathrm{Si}, \mathrm{Zn}, \mathrm{Mn}, \mathrm{Cu}$ of soils obtained from severe and low severity of blast disease, with five samples for each category. Data of agronomical factors (varieties, fertilizers rate, pesticides uses, organic matter uses) was cross tabulated against two level of blast severity and furthermore analyzed using $\chi 2$ test for significance association. Soil chemical properties that has different disease severity were analyzed. The agronomic factors associated with the high severity of lowland rice blast disease involves the use of Ciherang varieties, high frequency pesticides, and herbicides. Soil properties related to the rate of disease outbreak involves levels of N, P, K, S, Si, and soil micro-elements.
\end{abstract}

Keywords: Ciherang varieties, herbicides, macro elements, micro elements, Pyricularia oryzae

*Alamat penulis korespondensi: Departemen Proteksi Tanaman, Fakultas Pertanian, Institut Pertanian Bogor. Kampus IPB Darmaga, Jalan Kamper, Bogor 16680, Bogor 16680.

Tel: 0251-8629364, Faks: 0251-8629362; Surel: suryowi@apps.ipb.ac.id 


\section{PENDAHULUAN}

Beras merupakan bahan pangan pokok bagi masyarakat Indonesia. Produksi padi tahun 2012 mencapai 71.29 juta ton (BPS 2014). Sumbangan padi sawah untuk kebutuhan pangan nasional $90 \%$ dari produksi tersebut (Supriyanto 2013). Salah satu faktor pembatas dalam produksi ialah penyakit blas yang disebabkan oleh Pyrcularia oryzae (Hidayat et al. 2014).

Penyebaran penyakit blas sangat luas dan bersifat destruktif pada kondisi lingkungan menguntungkan. Penyakit ini telah menurunkan hasil panen padi di Asia Tenggara dan Amerika Selatan sekitar 30\%$50 \%$ (Scardaci et al. 1997). Serangan penyakit blas di Indonesia pada tahun 2007 mencapai 1285 juta ha atau $12 \%$ dari total luas areal pertanaman padi dan diramalkan serangan akan meningkat pada tahun-tahun mendatang (Ditjen Tanaman Pangan 2008). Cendawan ini juga mempunyai keragaman genetika yang tinggi (Ahn et al. 2000). Ras-ras patogen blas dapat berubah sifat virulensinya dalam waktu singkat, bergantung pada inang dan lingkungan (Utami et al. 2006).

Penyakit blas pada periode sebelumnya hanya merupakan penyakit penting pada padi gogo, tetapi setelah tahun 2010 menimbulkan masalah serius pada padi sawah (Sudir et al. 2014; Wiyono et al. 2014). Epidemi penyakit blas padi sawah dapat dikategorikan emerging disease yang mempunyai karakteristik insidensi penyakit meningkat dengan cepat, sebaran geografis bertambah, atau patogenisitas berubah (Anderson et al. 2005). Pendorong terjadinya emerging disease ialah introduksi patogen dari daerah atau negara/ daerah lain, perubahan iklim, perubahan teknik budi daya, perubahan habitat, peningkatan populasi vektor, dan perubahan genetik patogen Anderson et al. (2014). Pengetahuan tentang peran teknik budi daya dan sifat kimia tanah dalam perkembangan penyakit blas padi sawah sangat penting untuk mengembangkan strategi pengendalian dan pengetahuan ini belum tersedia. Tujuan penelitian ini ialah menganalisis kaitan teknik budi daya dan sifat kimia tanah dengan keparahan penyakit blas pada padi sawah di lapangan.

\section{BAHAN DAN METODE}

Penelitian dilaksanakan pada bulan Februari sampai dengan Maret 2014 di Laboratorium Peramalan Hama dan Penyakit (LPHP) Petarukan, Pemalang dan lima wilayah kecamatan di Kabupaten Pekalongan, Jawa Tengah dan sawah petani di berbagai kecamatan di Kabupaetn Pekalongan.

Pengumpulan Data Sekunder Serangan Blas. Data sekunder diperoleh dari Laboratorium Peramalan Hama dan Penyakit Petarukan, Pemalang. Data yang dikumpulkan ialah luas serangan penyakit blas pada tahun 2009-2013 dari Kabupaten Pekalongan, Jawa Tengah.

Wawancara Petani. Wawancara petani dilakukan secara langsung menggunakan kuisioner terstruktur tentang teknik budi daya. Hal ini dilakukan untuk memperoleh informasi tentang teknik budi daya yang dilakukan oleh petani dan pengetahuan petani terhadap penyakit blas, serta sejak kapan penyakit blas mulai terjadi di Kabupaten Pekalongan. Jumlah responden yang diwawancarai ialah 50 orang petani dari lima kecamatan dan lima desa wilayah pengamatan. Insidensi dan keparahan penyakit dilakukan dengan penentuan petak tanaman contoh yang dilakukan di lima kecamatan dan masingmasing satu desa per kecamatan. Data yang diperoleh dari wawancara ditampilkan dalam tabel kontingensi, dengan dua kolom, yaitu keparahan penyakit rendah dan tinggi, sedangkan baris terdiri atas berbagai faktor teknik budi daya: varietas, penggunaan pupuk organik, penggunaan pupuk $\mathrm{N} \mathrm{P} \mathrm{K}$, frekuensi penggunaan pestisida, dan teknik pengendalian gulma. Analiss $x^{2}$ digunakan untuk menentukan ada tidaknya kaitan antara teknik budi daya dan keparahan penyakit blas (Savary et al. 1995).

Pengamatan Lapangan. Petak yang diamati ialah lahan 10 petani responden wawancara untuk setiap desa sehingga jumlah lahan yang diamati ialah 50 petak lahan sawah. 
Tanaman contoh diambil dari setiap petak amatan, yaitu 10 tanaman secara diagonal. Pengamatan penyakit dilakukan secara langsung dengan mengamati gejala keparahan penyakit (KP) (\%). Pengukuran dilakukan dari masing-masing luas bercak penyakit blas pada daun padi. Pengamatan KP blas pada fase vegetatif ditentukan dengan rumus Townsend dan Heuberger (1943):

$$
\mathrm{KP}=\frac{\sum_{\mathrm{i}=0}^{i}\left(\mathrm{n}_{i} \times \mathrm{v}_{i}\right)}{\mathrm{N} \times \mathrm{V}} \times 100 \% \text {, dengan }
$$

ni, jumlah tanaman dengan skor ke-i; vi, nilai skor penyakit dari $\mathrm{I}=0,1,2$ sampai i t-skor tertinggi; $\mathrm{N}$, jumlah tanaman yang diamati; dan V, skor tertinggi. Skala kerusakan penyakit blas ditentukan berdasarkan "Standar Evaluation System for Rice" pada daun padi 0 123456789 (IRRI 1996).

Data KP dianalisis menggunakan Anova dan dibandingkan dengan nilai tengahnya dengan analisis DMRT. Program yang digunakan ialah SPSS for Window 6.0.

\section{Analisis Tanah}

Sebanyak lima sampel tanah dari masing masing kategori serangan ringan dan berat diambil pada kedalaman $30 \mathrm{~cm}$. Analisis tanah dilakukan di laboratorium tanah.

\section{HASIL}

Data serangan selama lima tahun (20092013) dan pengamatan lapangan memberikan gambaran bahwa penyakit blas telah menjadi masalah serius dalam produksi padi sawah di Kabupaten Pekalongan (Tabel 1). Kabupaten Pekalongan memiliki 19 kecamatan dan dilaporkan 11 kecamatan terserang penyakit blas dengan intensitas serangan ringan sampai sedang. Jumlah kecamatan yang terserang penyakit blas selama lima tahun ini juga mengalami peningkatan. Tahun 2009 hanya ada 2 kecamatan yang terserang penyakit blas dan pada tahun 2013 bertambah menjadi 9 kecamatan. Demikian juga luas total sawah yang terserang meningkat selama periode tersebut.

Serangan penyakit blas di lapangan yang diamati cukup tinggi pada lima kecamatan (Tabel 2). Serangan penyakit blas terjadi pada fase vegetatif awal, vegetatif akhir, dan fase generatif. Tampak serangan penyakit cenderung meningkat seiring meningkatnya umur tanaman.

\section{Teknik Budi Daya dan Perkembangan Penyakit Blas}

Beberapa faktor budi daya padi sawah berkaitan nyata dengan keparahan penyakit blas (Tabel 3). Teknik budi daya yang

Tabel 1 Luas serangan penyakit blas padi di 11 kecamatan, Kabupaten Pekalongan pada tahun 2009-2013

\begin{tabular}{lccccc}
\hline \multirow{2}{*}{ Kecamatan } & \multicolumn{5}{c}{ Luas sawah terserang (ha) } \\
\cline { 2 - 6 } & 2009 & 2010 & 2011 & 2012 & 2013 \\
\hline Lebakbarang & 0 & 0 & 0 & 0 & 3.6 \\
Petungkriyono & 0 & 0 & 0 & 0 & 8 \\
Talun & 0 & 0 & 0 & 2 & 75 \\
Doro & 0 & 8 & 0 & 20 & 46.5 \\
Karanganyar & 6 & 18 & 8 & 65 & 30 \\
Siwalan & 0 & 0 & 0 & 11 & 21 \\
Kajen & 4 & 14 & 8 & 14 & 17 \\
Kesesi & 0 & 295 & 149 & 163 & 65 \\
Bojong & 0 & 0 & 0 & 161 & 120 \\
Karangdadap & 0 & 2 & 16 & 20 & 0 \\
Wiradesa & 0 & 4 & 0 & 0 & 0 \\
\hline
\end{tabular}

Sumber: Laboratorium Pengamatan dan Peramalan Hama dan Penyakit Tanaman Pangan dan Hortikultura Petarukan (2014). 
berkaitan dengan perkembangan penyakit blas ialah varietas, frekuensi penggunaan pestisida, dan teknik pengendalian gulma. Varietas yang berasosiasi dengan keparahan tinggi ialah padi 'Ciherang'. Sebaliknya, padi 'Situbagendit' dan 'IR64' berasosiasi dengan keparahan rendah. Keparahan yang tinggi berasosiasi dengan penggunaan pestisida yang tinggi. Frekuensi penggunaan pestisida yang tinggi berkaitan nyata dengan keparahan penyakit blas yang tinggi. Teknik pengendalian gulma juga berkaitan dengan keparahan penyakit blas. Keparahan blas yang tinggi berkaitan dengan pengendalian gulma menggunakan herbisida. Sebaliknya, keparahan penyakit yang rendah berkaitan dengan pengendalian gulma mekanis.

\section{Hubungan Sifat Kimia Tanah Perkembangan Penyakit Blas}

Keparahan penyakit blas yang tinggi di lapangan berkaitan dengan N, P, S, dan unsur mikro $(\mathrm{Mn}, \mathrm{Cu}, \mathrm{Zn})$ yang tinggi. Keparahan penyakit blas yang tinggi juga berkaitan dengan kadar $\mathrm{K}$ dan Si tersedia tanah yang rendah (Tabel 4).

\section{PEMBAHASAN}

Penelitian ini memberikan konfirmasi bahwa keparahan penyakit blas pada padi sawah meningkat dengan pesat di Kabupaten Pekalongan pada tahun 2009-2013. Pengamatan lapangan juga membuktikan bahwa penyakit blas menjadi penyakit penting pada padi sawah. Sebelumnya penyakit blas merupakan penyakit penting pada padi gogo (Sudir et al. 2014) dan tidak penting sebagai penyakit padi sawah (Kim 1986).
Fenomena ini menarik untuk dikaji dan mencari tahu apa yang menjadi penentu dari epidemi penyakit blas pada padi sawah. Penelitian ini menunjukkan bahwa varietas merupakan salah satu faktor yang menentukan keparahan penyakit blas di lapangan. Tingkat keparahan penyakit yang tinggi berkaitan dengan penggunaan varietas Ciherang. Padi 'Ciherang' merupakan varietas yang rentan terhadap penyakit blas (Dewi et al. 2013).

Frekuensi penggunaan pestisida juga berkaitan dengan tingkat serangan yang tinggi. Penelitianinitidakdapatmenyimpulkanapakah penggunaan pestisida merupakan penyebab penyakit blas yang tinggi atau sebaliknya, yaitu terjadinya penyakit mendorong petani melakukan lebih banyak penyemprotan. Semua petani menggunakan insektisida untuk penyemprotan dengan bahan aktif mayoritas ialah tiamektosam, deltametrin, dimehipo, fipronil, dan sipermetrin. Sementara hanya $15 \%$ petani menggunakan fungisida dengan bahan aktif utama difenokonazol. Penentuan jenis bahan aktif insektisida yang digunakan oleh petani terhadap penyakit blas perlu diteliti untuk menentukan pengaruh bahan aktif tertentu terhadap keparahan penyakit blas.

Penggunaan herbisida berkaitan nyata dengan keparahan penyakit blas yang tinggi. Sebagian besar bahan aktif herbisida di lokasi penelitian ialah glifosat. Pada berbagai penelitian dari berbagai negara, glifosat dilaporkan menyebabkan tanaman rentan terhadap patogen, misalnya pada penyakit bercak daun yang disebabkan oleh Corynespora casiicola pada kedelai (Huber et al. 2005). Peningkatan kerentanan terhadap penyakit disebabkan oleh penghambatan glifosat terhadap produksi fitoaleksin (Johal

Tabel 2 Keparahan penyakit blas pada lima kecamatan di Kabupaten Pekalongan pada tahun 2014

\begin{tabular}{lrrc}
\hline \multirow{2}{*}{ Kecamatan } & \multicolumn{3}{c}{ Keparahan penyakit (\%) } \\
\cline { 2 - 4 } & Vegetatif awal & Vegetatif akhir & Generatif \\
\hline Kesesi & $5.13 \pm 3.36$ & $9.96 \pm 4.85$ & $11.72 \pm 7.13$ \\
Kajen & $5.80 \pm 3.99$ & $4.40 \pm 1.10$ & $12.60 \pm 6.17$ \\
Karanganyar & $10.66 \pm 4.22$ & $10.33 \pm 1.72$ & $11.37 \pm 1.05$ \\
Doro & $11.32 \pm 5.69$ & $44.76 \pm 8.49$ & $37.83 \pm 3.13$ \\
Talun & $12.16 \pm 8.64$ & $14.80 \pm 15.5$ & $25.25 \pm 7.69$ \\
\hline
\end{tabular}

$\mathrm{n}=50$ petak 
Tabel 3 Tabel kontingensi faktor budi daya padi sawah dan keparahan penyakit blas

\begin{tabular}{|c|c|c|c|c|c|}
\hline \multirow[t]{2}{*}{ Faktor budi daya } & & \multicolumn{2}{|c|}{ Jumlah petak dengan serangan } & \multirow[t]{2}{*}{$\chi^{2}$} & \multirow[t]{2}{*}{$P$} \\
\hline & & Rendah $\leq 25 \%$ & Tinggi $>25 \%$ & & \\
\hline \multirow[t]{8}{*}{ Varietas } & Ciherang & 17 & 4 & 14.75 & 0.039 \\
\hline & IR64 & 12 & 0 & & \\
\hline & Situbagendit & 7 & 0 & & \\
\hline & Mekongga & 2 & 0 & & \\
\hline & Sidenok & 2 & 2 & & \\
\hline & Umbul & 1 & 1 & & \\
\hline & Pertiwi & 1 & 0 & & \\
\hline & Unggul & 0 & 1 & & \\
\hline \multirow{2}{*}{$\begin{array}{l}\text { Penggunaan pupuk } \\
\text { organik }\end{array}$} & Menggunakan & 29 & 6 & 0.11 & 0.736 \\
\hline & Tidak menggunakan & 13 & 2 & & \\
\hline \multirow{3}{*}{$\begin{array}{l}\text { Dosis pupuk N } \\
\left(\mathrm{kg} \mathrm{ha}^{-1}\right)\end{array}$} & $\leq 50$ & 12 & 5 & 1.82 & 0.403 \\
\hline & $50<X \leq 100$ & 13 & 3 & & \\
\hline & $>100$ & 8 & 0 & & \\
\hline \multirow{3}{*}{$\begin{array}{l}\text { Dosis pupuk P } \\
\left(\mathrm{kg} \mathrm{ha}^{-1}\right)\end{array}$} & $\leq 50$ & 38 & 6 & 1.05 & 0.592 \\
\hline & $50<X \leq 100$ & 2 & 1 & & \\
\hline & $>100$ & 1 & 0 & & \\
\hline \multirow{3}{*}{$\begin{array}{l}\text { Dosis Pupuk K } \\
\left(\mathrm{kg} \mathrm{ha}^{-1}\right)\end{array}$} & $\leq 50$ & 38 & 5 & - & - \\
\hline & $50<\mathrm{X} \leq 100$ & 0 & 0 & & \\
\hline & $>100$ & 0 & 0 & & \\
\hline \multirow{3}{*}{$\begin{array}{l}\text { Frekuensi penggunaan } \\
\text { pestisida } \\
\text { (X per musim) }\end{array}$} & $\leq 3$ & 17 & 1 & 12.85 & 0.002 \\
\hline & $3<X \leq 5$ & 21 & 2 & & \\
\hline & $>5$ & 4 & 5 & & \\
\hline \multirow[t]{2}{*}{ Pengendalian Gulma } & Mekanis & 35 & 3 & 7.74 & 0.005 \\
\hline & Herbisida & 7 & 5 & & \\
\hline
\end{tabular}

Ket: $\mathrm{n}=50 ; \mathrm{P}<0.05$ menunjukkan ada hubungan nyata antara tenik budi daya dan keparahan penyakit blas, - , Tidak bisa dianalisis.

Tabel 4 Sifat kimia tanah pada dua tingkat serangan penyakit blas padi sawah di Kabupaten Pekalongan

\begin{tabular}{|c|c|c|}
\hline \multirow[t]{2}{*}{ Sifat kimia tanah } & \multicolumn{2}{|c|}{ Kandungan pada petak dan tingkat serangan penyakit blas } \\
\hline & Rendah & Tinggi \\
\hline \multicolumn{3}{|c|}{ Sifat Umum } \\
\hline $\mathrm{pH} \mathrm{H} \mathrm{H}_{2} \mathrm{O}$ & $4.65 \pm 0.07$ & $4.3 \pm 0.42$ \\
\hline C organik & $2.29 \pm 0.2$ & $2.54 \pm 0.07$ \\
\hline $\mathrm{N}$ total & $0.22 \pm 0.01$ & $0.26 \pm 0.007$ \\
\hline $\mathrm{C} / \mathrm{N}$ & $10.5 \pm 0.7$ & $10 \pm 0.0$ \\
\hline \multicolumn{3}{|c|}{ Hara makro (ppm) } \\
\hline P tersedia & $14 \pm 2.8$ & $23.5 \pm 3.5$ \\
\hline $\mathrm{K}$ & $31.5 \pm 9.1$ & $20 \pm 1.4$ \\
\hline $\mathrm{Ca}$ & $1592 \pm 120.2$ & $1750 \pm 31.1$ \\
\hline $\mathrm{Mg}$ & $127 \pm 15.5$ & $140 \pm 4.90$ \\
\hline $\mathrm{S}$ & $2.45 \pm 0.5$ & $11.7 \pm 0.9$ \\
\hline \multicolumn{3}{|c|}{ Hara mikro (ppm) } \\
\hline $\mathrm{Si}$ & $18.30 \pm 1.30$ & $16.75 \pm 0.49$ \\
\hline $\mathrm{Mn}$ & $118.5 \pm 4.50$ & $154.0 \pm 5.65$ \\
\hline $\mathrm{Cu}$ & $0.20 \pm 0.00$ & $0.25 \pm 0.07$ \\
\hline $\mathrm{Zn}$ & $1.45 \pm 0.05$ & $1.80 \pm 0.00$ \\
\hline
\end{tabular}


dan Huber 2009) dan juga efek merusak terhadap mikrob berguna yang ada di dalam tanah (Singh dan Ghosal 2010).

Keparahan penyakit blas yang tinggi terkait dengan kandungan unsur $\mathrm{K}$ dan $\mathrm{Si}$ yang rendah dalam tanah. Hal ini sejalan dengan berbagai penelitian bahwa $\mathrm{K}$ dan $\mathrm{Si}$ berperan dalam ketahanan tanaman terhadap penyakit, termasuk penyakit blas (Seebold et al. 2001; Syarif et al. 2015; Wattanapayapkul et al. 2020). Rendahnya K dan Si yang tersedia bagi tanaman diduga merupakan salah satu aspek yang menjelaskan tentang berkembangnya penyakit blas pada padi sawah. Husnain et al. (2010) menyatakan bahwa neraca hara $\mathrm{K}$ dan Si pada sawahsawah di pantai utara Jawa Barat ialah negatif karena tidak adanya pengembalian jerami dan rendahnya pemupukan $\mathrm{K}$.

Kadar N, P, dan S yang tinggi meningkatkan kerentanan terhadap penyakit blas. Peran N yangtinggi diketahuimeningkatkankerentanan tanaman terhadap penyakit tertentu, salah satunya ialah karena peningkatan sukulensi dan peningkatan protein dalam jaringan tanaman (Huber dan Haneklaus 2007). Sementara unsur $\mathrm{P}$ yang berlebih dapat menyebabkan perubahan aktivtias enzim yang berujung pada peningkatan kerentanan tanaman padi terhadap penyakit blas (Campos-Soriano et al. 2020). Peran kelebihan unsur S pada ketahanan terhadap penyakit blas perlu diteliti lanjut. Fenomena bahwa keparahan penyakit blas yang tinggi berkaitan dengan kadar unsur mikro $\mathrm{Mn}, \mathrm{Cu}$, dan $\mathrm{Zn}$ merupakan hal yang menarik untuk dikaji.

Perkembangan blas padi sawah berkaitan dengan teknik budi daya dan sifat kimia tanah sawah. Penggunaan varietas Ciherang, frekuensi penggunaan pestisida yang tinggi, penggunaan herbisida, sifat kimia tanah $\mathrm{K}$ dan Si yang rendah, N, P, S, serta unsur mikro yang tinggi berperan penting dalam epidemi penyakit blas pada padi sawah di lapangan.

\section{DAFTAR PUSTAKA}

Ahn SN, Yeon KK, Cheol H, Seong SH, Kwon SJ, Chune H, Huhn PM, Susan R. 2000.
Molecular mapping of a new gene for resistance to rice blast (Pyricularia grisea Sacc.). J Euphytica. 116(1):17-22.

Anderson PK, Cunningham AA, Patel NG, Morales, FJ, Epstein PR, Daszak P. 2004. Emerging infectious diseases of plants: pathogen pollution, climate change and agrotechnological drivers. Trends Ecol Evol. 19(10):535-544. DOI: https://doi. org/10.1016/j.tree.2004.07.021.

[BPS] Badan Pusat Statistik. 2014. Produksi padi, jagung, dan kedelai [Internet] [diunduh 2014 Mei 5]. Tersedia pada: http://www.bps.go.id.

Campos-Soriano L, Bundó M, Bach-Pages M, Chiang SF, Chiou TJ, San Segundo B. 2020. Phosphate excess increases susceptibility to pathogen infection in rice. Mol Plant Pathol. 21(4):555-570. DOI: https://doi.org/10.1111/mpp.12916.

Dewi IM, Abdul L, Anton M. 2013. Hubungan karakteristik jaringan daun dengan tingkat serangan penyakit blas daun pada beberapa genotype padi. JHPT Tropika. 1(2):10-18.

[Ditjentan] Direktorat Jenderal Pertanian Tanaman Pangan. 2008. Pengalaman dari 2007 dan mensukseskan MT 2007/2008 [Internet] [diunduh 2014 Mei 28]. Tersedia pada: http://ditjentan.deptan.go.id/index. php. option.

Hidayat YS, Nurdin M, Suskandini RD. 2014. Penggunaan Trichoderma sp. sebagai agensia pengendalian terhadap Pyricularia oryzae Cav. penyebab blas pada padi. J Agrotek Tropika. 2(3):414-419.

Huber DM, Haneklaus S . 2007. Managing nutrition to control plant disease. Landbauforschung Völkenrode. 4(57):313-322.

Huber DM, Cheng MW, Winsor BA. 2005. Association of severe Corynespora root rot of soybean with glyphosate-killed giant ragweed. Phytopathology. 95(6):S45

Husnain, Masunaga T, Wakatsuki T. 2010. Field assessment of nutrient balance under intensive rice-farming systems, and its effects on the sustainability of rice production in Java Island, Indonesia. J Agric Food Environ. 4:1-11. 
[IRRI] International Rice Research Institute. 1996. Standard Evaluation System for Rice. Ed ke-4. Los Banos (PH): IRRI.

Johal GS, Huber DM. 2009. Glyphosate effects on diseases of plants. Europ $\mathrm{J}$ Agron. 31(3):144-152. DOI: https://doi. org/10.1016/j.eja.2009.04.004.

Kim CH. 1986. Effect of water-management on the etiology and epidemiology of rice blast caused by Pyricularia oryzae Cav. LSU Historical Dissertations and Theses. 4246. https://digitalcommons.lsu.edu/ gradschool_disstheses/4246.

Savary S, Madden V, Zadoks JC, KleinGebbinck HW. 1995. Use of categorical information and correspondence analysis in plant disease epidemiology. Adv Bot Res. 21:213-240. DOI: https://doi. org/10.1016/S0065-2296(08)60014-2.

Scardaci SC, Webster RK, Greer CA, Hill JE, William JF, Mutters DM, Brandon RG, Kenzi KS, Oster JJ. 1997. Rice blast: a new diseases in California. J Agric Fact Sheet Ser. 2:1-2.

Seebold KW, Kucharek TA, Datnoff LE, Victoria FJ, Marchetti MA. 2001. The influence of silicon on components of resistance to blast in susceptible, partially resistant and resistant cultivars of rice. Phytopathology. 91:63-69. DOI: https:// doi.org/10.1094/PHYTO.2001.91.1.63.

Singh P, Ghoshal N. 2010. Variation in total biological productivity and soil microbial biomass in rainfed agroecosystems: Impact of application of herbicide and soil amendments. Agric Ecosyst Environ. 137(3-4):241-250. DOI: https://doi. org/10.1016/j.agee.2010.02.009.

Sudir S, Nasution A, Santoso S, Nuryanto B. 2014. Penyakit blas Pyricularia grisea pada Tanaman Padi dan Strategi Pengendaliannya. Iptek Tanaman Pangan. 9(2):85-96.

Supriyanto B. 2013. Pengaruh cekaman kekeringan terhadap pertumbuhan dan hasil padi gogo lokal kultivar jambu (Orysa Sativa Linn). J Agrifor. 7(1):77-82.

Syarif AS, Wiyono S, Sukarno BPW, Purwoko BS. 2017. Role of rice straw compost and potassium in controlling blast disease of paddy rice in South Sulawesi, Indonesia. Int J Sci Basic App Res. 36(4):244-254.

Townsend GR, Heuberger JW. 1943. Methods for estimating losses caused by diseases in fungicide experiments. Plant Dis Rep. 27(17):340-343.

Utami DW, Aswidinnoor H, Moelyopawiro S, Hanarida I, Reflinur. 2006. Pewarisan ketahanan penyakit blas (Pyricularia grisea Sacc.) pada persilangan padi IR64 dengan Oryza rufipogon Griff. HAYATI J Biosci. 13(3):107-112. DOI: https://doi. org/10.1016/S1978-3019(16)30302-3.

Wattanapayapkul W, Polthanee A, Siri B, Badalung NN, Prmkhambut A. 2011. Effect of silicon insuppresing blast disease and increasing grain yield of organic rice in Northeast Thailand. Asian J Plant Pathol. 5(4):134-145. DOI: https://doi. org/10.3923/ajppaj.2011.134.145.

Wiyono S, Widodo, Triwidodo H. 2014. Managing outbreak of rice pest and diseases in fragile agroecocystem by biointensive integrated pest management (dalam Bahasa Indonesia). Risalah Kebijakan Pertanian dan Lingkungan 1(2):5-10. DOI: https://doi.org/10.20957/ jkebijakan.v1i2.10303. 